\title{
The attitudine of the typical students towards the inclusion of their colleagues with special educational needs in mass education
}

Nicoleta Raluca Lupu 


\title{
The attitudine of the typical students towards the inclusion of their colleagues with special educational needs in mass education
}

\author{
Nicoleta Raluca Lupu ${ }^{a^{*}}$ \\ ${ }^{a}$ Transylvania University, Faculty of Psychology and Education Sciences, 56 N. Balcescu Street, Brasov,500036, Romania
}

*Corresponding author: nicoleta.lupu@unitbv.ro

Abstract

Keywords: Integration, attitude,

special needs, mass education, typical student
The present article is a quantitative research which responds to the following question: what is the attitude of the typical students towards the inclusion of their colleagues with special needs. The attitudes of typical students were measured using a scale designed for this purpose. The results showed a positive attitude towards inclusion. The attitude was also influenced by factors such as gender. Through the paper "Educational Implications of Game in Students with Special Educational Needs from Inclusive Schools", a new way of inclusion was suggested, the inclusion through game addressed to the whole community. The key groups involved in the inclusion process and the proposed objectives for each target group are thus presented: teaching staff: 1) identifying teachers' attitudes towards the integration of the students with special needs in mass education, 2) changing the teachers' attitudes through games; students with special educational needs: 1) designing and testing some forms of support through game; the parents of typical students: 1) identifying the attitudes towards the integration of students with special needs in mass education; typical students: 1) identifying the attitude towards the integration of students with special educational needs in mass education

\section{Zusammenfasung}

\section{Schlüsselworte:}

Integration,

Einstellung,

besondere

Bedürfnisse

Massenerziehung,

typischer Student
Durch das Papier "Pädagogische Implikationen des Spiels bei Schülern mit sonderpädagogischem Förderbedarf aus den inklusiven Schulen" wurde eine neue Art der Inklusion vorgeschlagen, die Inklusion durch Spiel für die gesamte Gemeinschaft. Die am Einbeziehungsprozess beteiligten Schlüsselgruppen und die vorgeschlagenen Ziele für jede Zielgruppe werden folgendermaßen dargestellt: LEHRPERSONAL: 1) Ermittlung der Einstellungen der Lehrer zur Integration von Schülern mit besonderen Bedürfnissen im Massenunterricht, 2) Änderung der Einstellungen der Lehrer durch Spiele; STUDENTEN MIT BESONDEREN BILDUNGSBEDÜRFNISSEN: 1) Entwerfen und Testen einiger Formen der Unterstützung durch das Spiel; DIE ELTERN typischer Schüler: 1) Ermittlung der Einstellungen zur Integration von Schülern mit besonderen Bedürfnissen in der Massenerziehung; TYPISCHE STUDIERENDE: 1) Ermittlung der Einstellung zur Integration von Schülern mit sonderpädagogischem Förderbedarf in den Massenunterricht

Bei dem vorliegenden Artikel handelt es sich um eine quantitative Untersuchung, die folgende Frage beantwortet: Wie stehen die typischen Studierenden zur Einbeziehung von Kolleginnen und Kollegen mit besonderen Bedürfnissen? Die Einstellungen typischer Schüler wurden anhand einer für diesen Zweck entwickelten Skala gemessen. Die Ergebnisse zeigten eine positive Einstellung zur Inklusion. Die Einstellung wurde auch von Faktoren wie Geschlecht beeinflusst.

\section{Introduction}

\subsection{The attitude, general characterization}

In the literature, there are several definitions of attitude, being an intensively studied field in social psychology. Iluţ (2004) explains the interest manifested through its complexity and its multiple facets. The analysis of the definitions in the literature, Luthans (1985), Murray (1938), Grigoruţă (2005), Bogardus (1931), Tapia (1991), Folsom (1931), Eiser, Van Den Plight (1988), Moscovici (1998), Droba (1933), Drăgan, Demetrescu (1996), Roşca (1943), Albig apud Chircev (1941), Bernard (1927), Mărgineanu (1938), Chircev (1941), Stoetzel
(1963), Boza (2010), Popescu-Neveanu (1978), Chelcea apud Chelcea, Iluţ (2003), Vrabie (1975) allows outlining the following definition of the attitude: a sum of emotional reactions, provisions, more or less durable, stable, conscious or unconscious evaluations which entail a behaviour, an action regarding the object of attitude (situations, ideas, people, one's own person) and which appear on the background of one's own personality, own beliefs, values or under the influence of the social group which manifest themselves with a greater or lesser intensity, in a positive or negative manner, of rejection or acceptance. 
According to Chircev (1941) the characteristics of attitude are divided into dominant characteristics and secondary characteristics. Boza (2010) reminds of the properties of attitude, raising the following question regarding the characteristics of attitudes: are attitudes temporary constructions or stable entities?

As for the functions of attitudes, Katz (1960) mentions four functions: adaptative function, cognitive function, expressive function, the defence function.

Regarding the classification of attitudes, Brown apud Chircev (1941) recalls seven types of attitudes: group attitudes, unconscious attitudes, objective and nonobjective attitudes, complex and specific attitudes, organic and social attitudes.

The attitude consists of three components that interact with each other, having different inputs in forming the attitude. It is what Neculau (2004), Chelcea (2008) call "the three-dimensional model of attitude": the cognitive component (opinions, beliefs, convictions), the behavioural component (the manifested behaviour), the emotional component.

Eiser \& Van Den Plight (1988) consider that measuring attitudes is difficult because they are not visible, being measured indirectly. Chircev (1941) lists the following methods for measuring attitudes: 1) The census method, 2) The method of the questionnaire, 3) Opinion tests, 4) Situation tests.

\section{Forming attitudes}

Chircev (1941) describes the individual factors and the social factors that determine the formation of attitudes.
Individual factors include age, gender, race, intelligence, temperament, the emotional stability and instability, the tendency towards domination or obedience. Social factors include family, school, church, economic conditions, background, social class, parents' profession, access to information in general, propaganda, the press. Attitudes formation is also explained by the following learning models: contiguous learning, learning through reinforcement, learning through observation. Contextual influences also contribute to the formation of an attitude. Boza (2010) mentions among them goals, mood, body condition, standards and ease of updating information.

\section{Research Methodology}

The objective of this research is to identify the attitude of the typical students towards the integration of students with special educational needs in mass education.

Starting from this objective, the following hypothesis are formulated:

Hypothesis 1: The students' attitude is influenced by the degree of proximity to the people with special needs.

Hypothesis 2: There are significant correlations between attitude and the socio-professional characteristics such as gender and studies.

\subsection{Participants}

The students participating in the study come from the urban environment, primary and secondary schools. Out of the 132 students, 82 are enrolled in primary education and 50 students in secondary education (fig. 1).

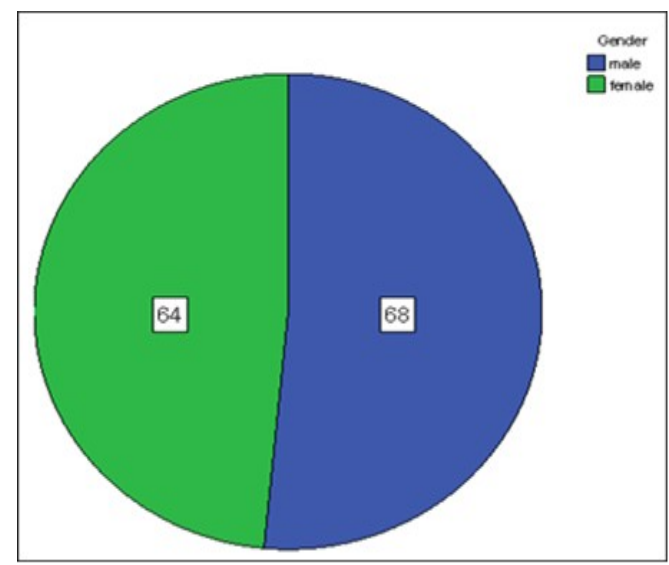

Figure 2. Distribution of participants by gender
Figure 1. Distribution of participants by studies

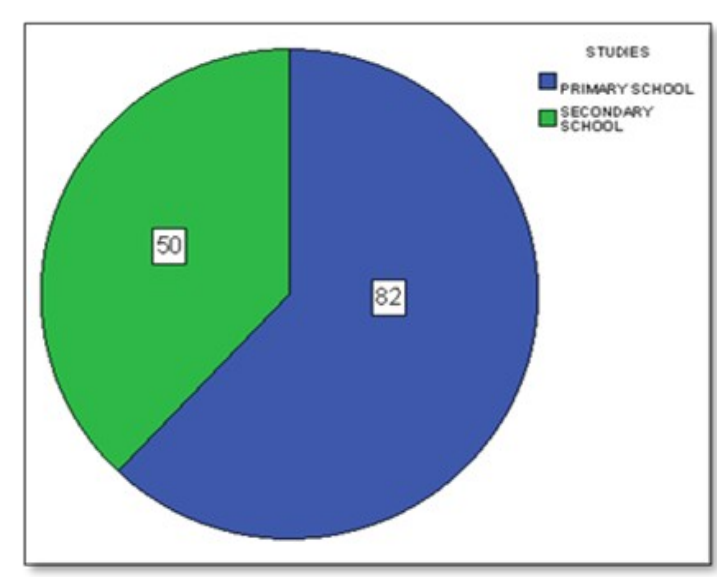




\subsection{Instruments}

The attitudes of the typical students were measured using a scale designed for this purpose. The scale is made up of 25 items distributed in three sub-scales, of which 11 are items with reverse scoring: Subscale I- General attitude towards the people with special needs (3 items), Subscale II- Attitude towards the integration of students with special educational needs in their own school (9 items), Subscale III - Attitude towards the integration of students with special educational needs into their own class (13 items). The scale has an internal consistency coefficient of .76. The first subscale has an Alpha coefficient of .64, the second a coefficient of .60, and the third subclass a coefficient of .63. There are strong correlations between the scale and its subscales at a $\mathrm{p}$ $<.01$. The Kolmogorov-Smirnov test shows that there are no statistically significant differences between the distribution of the variables involved and the normal distribution, to a $\mathrm{p}>.05$ in the case of the variables "the attitude towards the total integration" and "the attitude towards the integration in the class".

The statistical processing of data will be achieved by applying the SPSS computerized program.

\section{Procedure}

The following procedure was observed in order to achieve the objective:

- Informing the school headmasters about the conduct of this research and obtaining the agreement

- Informing the teachers and the parents of the students and obtaining the participation agreement

- Applying the instruments

- Data input and presentation of the results

- Presentation of the final conclusions

\section{Results}

\section{Hypothesis I}

The students' attitude is influenced by the degree of proximity to the people with special needs.
The "attitude" variable has three dimensions: the attitude towards the integration of the people with disabilities in society and in mass education, the attitude towards the integration of the students with special educational needs in their own school, the attitude towards the integration of the students with special educational needs in their own class.

It can be noticed (fig.3) that the environments obtained by the students participating in the three subscales increase from an average of 13.03 regarding the general attitude to an average of 49.66 regarding the specific attitude towards the integration of the students with special educational needs in their own class. So, the degree of proximity affects the attitude positively.

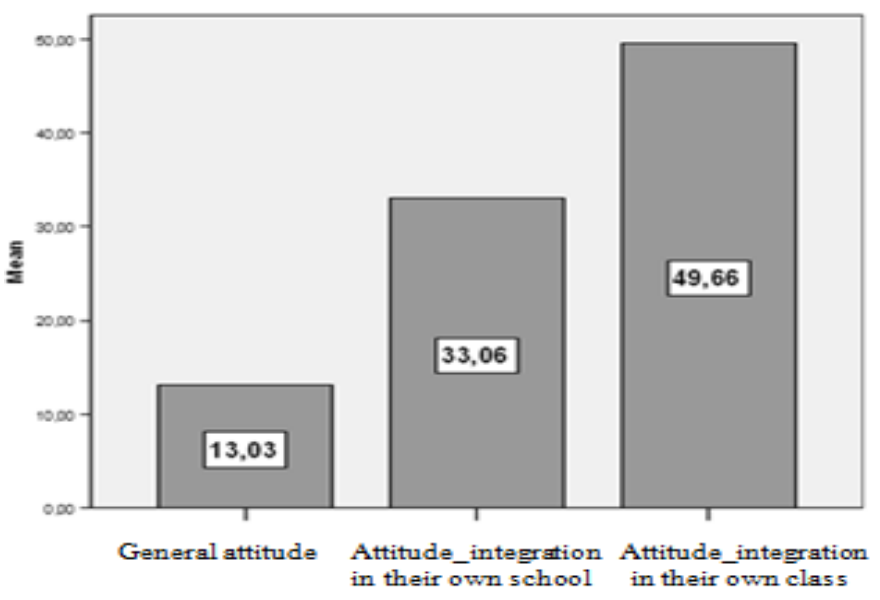

Figure 3. Distribution of participants by studies

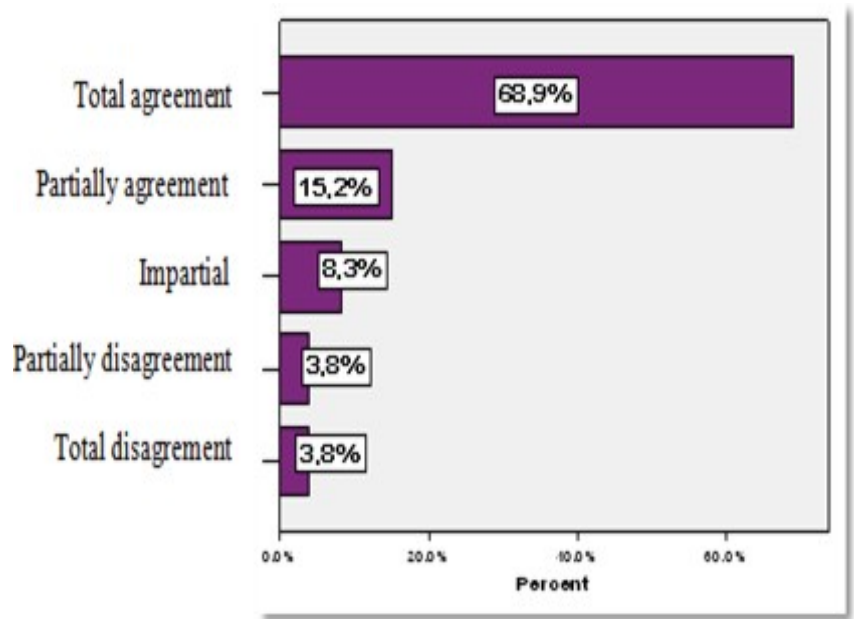


For a better analysis of the results, the students' answers to the key questions in the questionnaire are presented through the census method.

Most of the questioned students totally (68.9\%) and partially agree $(15.2 \%)$ that disabled people have the right to go to school (fig. 4)

Figure 4. The students' answers regarding the right to education of persons with special needs

In terms of schooling, only $12.12 \%$ of students believe that the place of children with special educational needs is in the special school (fig. 5).

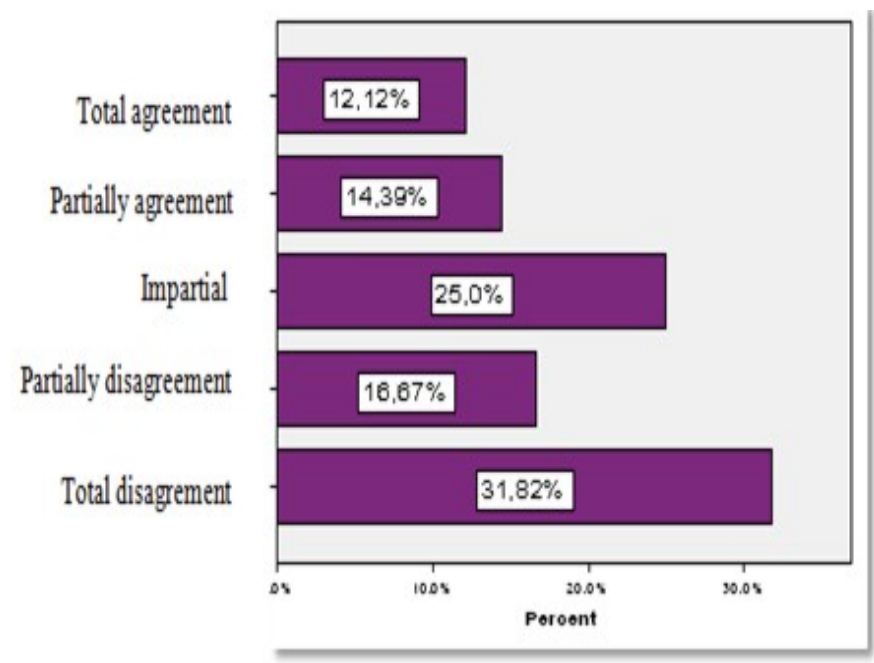

Figure 5. The students' answers regarding the form of schooling of students with special needs

Although most of the questioned students consider that the place of children with special educational needs is not in the special school, the severity of the disability influences the attitude towards integration, $29,55 \%$ and $15,15 \%$ of the students totally and partially agreeing that the students with severe deficiencies should not attend a regular school.

In contrast, the students with minor disabilities are accepted in inclusive schools, $27.27 \%$ and $28.03 \%$ of students being totally and partially in favour of their integration.

Regarding the image of the school and of their own class, $53.8 \%$ of the students questioned consider that the image of the school is affected by the presence of colleagues with special educational needs because they do not have good results and can give cause for ridicule.

Also, $55.3 \%$ of students totally agree that students with special needs lower the level of the class and 37.9\% think that these colleagues disturb the activity and monopolize the teacher's attention to the detriment of the other children.

It is interesting to note that although most of the questioned students consider that the integration of peers with special needs affects the image of the school and the class, $73.5 \%$ fully agree that the school should be adapted to the needs of these students.

In addition, students show tolerance towards their disabled colleagues and although they disturb and monopolize the teacher's attention, $63.6 \%$ think that this category of students should be understood by the teachers in terms of evaluation.

Moreover, $47 \%$ of students think they need to help their colleagues with special needs to learn.

Regarding social integration, $76.5 \%$ of the surveyed students are totally in agreement with the statement "Students with special educational needs can have friends" and $54.5 \%$ accept the integration of their peers with special needs in the normal classes in order to make friends, although $41,7 \%$ think that these students will not learn anything. If for peers with special needs, an advantage of the integration in mass education is the formation of new friendships, for the typical students, an advantage could be the development of empathy.

A total of $30.3 \%$ of the questioned students are undecided if the presence of their colleagues with special educational needs could make them better.

\section{Hypothesis 2}

There are significant correlations between attitude and the socio-professional characteristics such as gender and studies. 
The results (table no.1) show statistically significant correlations between the attitude towards the integration of students with special educational needs in school and class $(\mathrm{r}=0.19, \mathrm{p}<.05)$ and the participants' gender. Regarding the relationship between attitude and studies (primary and secondary), a statistically significant correlation is noted between the studies and the attitude towards the integration of students with special educational needs in class $(\mathrm{r}=-0.27, \mathrm{p}<.01)$. Gender and studies do not influence the general attitude towards the integration of people with special educational needs into society.

Table 1. Correlations between student attitudes and socioprofessional characteristics

\begin{tabular}{|c|c|c|c|}
\hline & & Gender & Studies \\
\hline General & Pearson &, 06 &,- 08 \\
\hline & Sig. & ,48 & ,36 \\
\hline & $\mathrm{N}$ & 132 & 132 \\
\hline Attitude_school & Pearson & ,19 &,- 15 \\
\hline & Sig. & $\begin{array}{l}, 02 \\
\mathrm{p}<.05\end{array}$ & 08 \\
\hline & $\mathrm{N}$ & 132 & 132 \\
\hline Attitude_Class & Pearson & ,19 &,- 27 \\
\hline & Sig. & $\begin{array}{l}, 02 \\
\mathrm{p}<.05\end{array}$ & $\begin{array}{l}, 00 \\
p<.01\end{array}$ \\
\hline & $\mathrm{N}$ & 132 & 132 \\
\hline
\end{tabular}

The $\mathrm{T}$ test for independent samples (tab. 2) shows statistically significant differences between boys and girls as regards the attitude towards the integration of students with special educational needs in their own school $(\mathrm{t}=$ $2.20, \mathrm{p}<.05)$ and class $(\mathrm{t}=2.26, \mathrm{p}<.05)$.

Girls are more tolerant than boys in accepting colleagues with special needs in their own school and class. Regarding the general attitude towards the integration of the people with disabilities in society, there are no significant differences.
Table 2. Differences between boys and girls as regards the attitude towards the integration of students with special educational needs in their own school and class

\begin{tabular}{|l|l|l|l|l|l|}
\hline Var. & Gr. & $\mathrm{N}$ & Means & $\mathrm{t}$ & $\mathrm{p}$ \\
\hline Attitude_school & $\mathrm{M}$ & 68 & 31,97 & 2,20 & $\begin{array}{l}.02, \\
\mathrm{p}<.05\end{array}$ \\
\hline & $\mathrm{F}$ & 64 & 34,21 & & \\
\hline Attitude_class & $\mathrm{M}$ & 68 & 48,27 & 2,26 & $\begin{array}{l}.02, \\
\mathrm{p}<.05\end{array}$ \\
\hline & $\mathrm{F}$ & 64 & 51,12 & & \\
\hline
\end{tabular}

\section{Conclusion}

The degree of proximity to this category of students influenced the attitude positively. The closer they approached, the more the students participating showed a greater degree of tolerance and acceptance. The attitude of the community was also influenced by factors such as the male students and the female students.

The results obtained are supported by other studies from the specialized literature (Adet, Pomohaci, 2016, Cheianu, 2011, Malcoci et all, 2015, Horga, 2009), the attitude of typical students towards their colleagues with special needs being influenced by certain factors such as school success, the degree and type of the deficiency, the social image.

\section{Contributions \\ Application value}

The research results can be used at the institutional level in the activity of the school psychologists in mass education in combating discrimination and the formation of an inclusive policy.

\section{Authors note:}

Nicoleta Raluca Lupu Assistant Prof. PhD., Transylvania University, Faculty of Psychology and Education Sciences. Topic of interest: Special Education

\section{References}

Adet, N., Pomohaci, C.M. (2016). Relaționarea elevilor cu CES $\mathrm{cu}$ colegii lor din perspectiva educației incluzive. Revista de Pedagogie, LXIV (1), 99-110.

Bernard, L.L. (1927). An introduction to Social Psychology. London: G. Allen\&Unwin. 
Bogardus, E., S. (1931). Fundamentals of Social Psychology. New-York: Century Company.

Boza, M. (2010). Atitudinile sociale şi schimbarea lor. Iaşi: Polirom.

Cheianu-Andrei, D. (2011). Studiu comparativ privind cunoștințele, atitudinile și practicile în domeniul incluziunii educaționale a copiilor cu CES la nivel de familie, școală, comunitate. Chișinău: Centrul de Investigații și Consultanță Sociopolis.

Chelcea, S., Iluț, P. (2003). Enciclopedie de Psihosociologie. București: Editura Economică.

Chelcea, S. (2008). Psihosociologie: teorii, cercetări, aplicaţii. Iaşi: Polirom.

Chircev, A. (1941). Psihologia atitudinilor sociale. Cu privire specială la români. Sibiu: Editura Institutului de Psihologie al Universității Cluj.

Drăgan, J., Demetrescu, M. (1996). Practica prospectării pieţei. București: Editura Europa Nova.

Droba, D.D. (1933). The nature of attitudes. Journal of Social Psychology, 4, pp. 444-463.

Eiser, J.R., J. Van Den Plight. (1988). Attitudes and Decisions. London: The Guernsey Press.

Folsom, I.C. (1931). Social Psychology. New-York: Harper\&Brothers.

Grigoruță, M.V. (2005). Atitudini și comportament: o abordare psihologică a procesului organizational. Management Intercultural, vol. VII, nr. 12, pp. 10-18.
Horga, I. (2009). Educația copiilor cu CES în învățământul de masă, demers de personalizare în școala românească. Revista de Pedagogie, 7-9, pp. 143-156.

Iluţ P. (2004). Valori, atitudini şi comportamente sociale: teme actuale de psihosociologie. Iaşi: Polirom.

Katz, D. (1960). The functional approach to the study of attitudes. Public Opinion Quartely, 24(2), pp. 163-204.

Luthans, F. (1985). Organisational Behaviour. McGraw-Hill.

Malcoci, L., Chistruga-Sinchevici, I. (2015). Incluziunea elevilor cu CES în școlile din comunitate. Studiu sociologic. Chișinău: Alianța ONG-urilor, Global Campaign for Education, Swedish Organization for Individual Relief.

Mărgineanu, N. (1938). Măsurarea atitudinilor sociale. Revista de Psihologie, 1, pp. 10-32.

Moscovici S. (1998). Psihologia socială a relatiilor cu celălalt. Iaşi: Polirom.

Murray, H. (1938). Explorations in Personality. New-York: Oxford University Press.

Neculau, A. (2004). Manual de psihologie socială. Iași: Polirom.

Popescu-Neveanu, P. (1978). Dicționar de psihologie. București: Editura Albatros.

Roșca, Al. (1943). Motivele acțiunilor umane. Sibiu: Editura Institutului de Psihologie al Universității.

Stoetzel, J. (1963). La psychologie sociale. Paris: Flammarion

Tapia, C. (1991). Les attitudes. Paris: Les Editions d'Organisation.

Vrabie, D. (1975). Atitudinea elevului față de aprecierea şcolară. București: Editura Didactică și Pedagogică. 